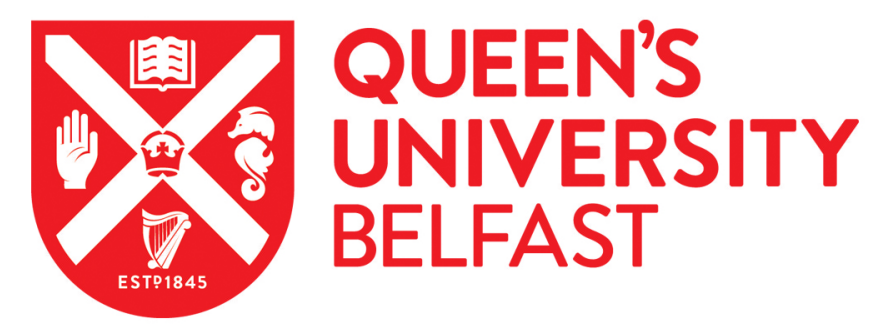

\title{
Problematising the use of education to address social inequity: could Participatory Action Research be a step forwards?
}

Giannakaki, M-S., McMillan, I. D., \& Karamichas, J. (2018). Problematising the use of education to address social inequity: could Participatory Action Research be a step forwards? British Educational Research Journal, 44(2), 191-211. https://doi.org/10.1002/berj.3323

Published in:

British Educational Research Journal

Document Version:

Peer reviewed version

Queen's University Belfast - Research Portal:

Link to publication record in Queen's University Belfast Research Portal

\section{Publisher rights}

(c) 2018 British Educational Research Association. This work is made available online in accordance with the publisher's policies. Please refer to any applicable terms of use of the publisher.

\section{General rights}

Copyright for the publications made accessible via the Queen's University Belfast Research Portal is retained by the author(s) and / or other copyright owners and it is a condition of accessing these publications that users recognise and abide by the legal requirements associated with these rights.

Take down policy

The Research Portal is Queen's institutional repository that provides access to Queen's research output. Every effort has been made to ensure that content in the Research Portal does not infringe any person's rights, or applicable UK laws. If you discover content in the Research Portal that you believe breaches copyright or violates any law, please contact openaccess@qub.ac.uk. 
Problematising the use of education to address social inequity: could Participatory Action Research be a step forwards?

Marina-Stefania Giannakaki, Ian David McMillan, and John Karamichas Queen's University Belfast, UK

${ }^{*}$ Corresponding author: John Karamichas, School of Social Sciences, Education, and Social Work, Queen's University Belfast, 6 College Park, BT7 1LP. Email address:

j.karamichas@,qub.ac.uk 


\section{Problematising the use of education to address social inequity: could Participatory Action Research be a step forwards?}

This paper critiques international trends towards certain school practices aimed at promoting equity and social justice by closing gaps in specific learning outcomes among students. It argues that even though some of these practices (e.g. individualised student support, data-driven leadership) improve learning outcomes for certain groups considered 'disadvantaged', they fail to have a genuine impact on the issue. They remain 'locked' in the logic of social mobility, reaffirming the legitimacy of a hierarchical system underpinned by competitive individualism which unfairly distributes social opportunities under the guise of 'merit' and 'justice'. The paper argues that unless students develop awareness of the subtle injustices legitimised by the current system, no specialised interventions will ever tackle inequity, but will, instead, reinforce it. Yet, attempts to explicitly challenge mainstream school practices are likely to face harsh resistance from system agents due to being so ingrained in school cultures. An alternative strategy is suggested which, without being too subversive, could raise students' awareness - what Freire (1996) called 'conscientização'. This would entail the application of Participatory Action Research (PAR) under the cloak of traditional (system-aligned) Action Research. Such PAR, despite its political character, would initially appear to fulfil the performative role of more technical interventions (e.g. raising test scores) but in a way that 'conscientização' also happens in the process. This may set the ground for social reform, encouraging the transition to a more sustainable and equitable society based on collectivity and solidarity.

Keywords: social justice, equity, participatory action research, school education 


\section{Introduction}

An international trend in school education in countries as varied as England, New Zealand, USA, Finland, Italy, Sweden, or South Africa has been the implementation of programmes or practices focused on equalising learning outcomes between different student groups to promote equity and social justice (MacBeath \& Mortimore, 2001; Murray \& Malmgren, 2005; Grubb, 2007; Ainscow et al., 2010; Ndlovu, 2011; Faubert, 2012; Grimaldi, 2012; Ball, 2013; Payne, 2013; Persson, 2013; Meissel et al., 2016). At the same time, a body of scholarly literature critiques such programmes as lacking substance, appropriating equity discourses without genuinely serving their purpose (Oakes, 2005; Gillborn, 2006; Gorski, 2008; Loughland \& Sriprakash, 2016). The argument articulated in this literature is that the root causes of inequity - which, in basic education, becomes evident as systematic underachievement, 'anti-social' behaviour, or low future income of certain student groups - is inappropriately located within individuals, families, or communities. Established hierarchical structures generating such inequities (e.g. school assessment regimes) remain unquestioned. These structures sort individuals on limited criteria institutionalised as 'valid' (e.g. performance on standardised tests, conformity with school norms), classifying students, either formally or informally, into different levels of 'ability' or 'worth' which only a minority eventually transcend. In this way, human relations are made to be unequal and oppressive, while such oppression is viewed as natural for those considered of 'lesser value'. This deficit perspective misinterprets the outcomes of structural inequity as its root causes. Ensuing interventions focus on remedying the assumed deficiencies of certain students (e.g. through additional 'support') leaving structural injustices intact (Gillborn, 2006; Apple, 2008; Irizzary, 2009; Poulter, 2016).

Gillborn (2006), who deals with citizenship education programmes aiming to combat racism in England, contributes to the above critique. He refers to these programmes as 'public policy placebos' (p. 83) seeking to appease the public, yet lacking an effective ingredient. Such 
programmes view racism as product of the thinking and doing of certain individuals who must be helped to overcome prejudice and develop pro-social behaviours. Racism is, therefore, personalised and its institutionalised forms ignored (e.g. ability grouping based on attainment in English which disadvantages certain minorities). The personalisation of good citizenship is also apparent in relevant programmes in other countries (e.g. South Africa, Norway, Israel, Cyprus, Finland, or USA). These promote a depoliticised notion of citizenship by aiming to foster, in individual students, attitudes and behaviours conforming to dominant social mores (e.g. reading newspapers, volunteering) while overlooking the subtle operation of school structures that socially exclude certain groups and render them, eventually, 'non-citizens' (Geobers et al., 2013; Staeheli \& Hammett, 2013; Expósito, 2014; Hilburn \& Maguth, 2015; Poulter, 2016; Straume, 2016).

Similarly, Wrigley (2008) and Wilkins (2015) critique school effectiveness and improvement programmes aiming to help traditionally disadvantaged groups do better academically, access higher education, or increase their employability through interventions of a technical nature. These programmes, and the successes they often bring about for individual students, overshadow the structural underpinnings of inequity, reducing the likelihood of students or teachers developing transformative action.

This paper argues that unless students and teachers develop awareness of institutionalised injustices - what Freire (1996, p. 90) referred to as 'conscientização' (critical consciousness) - no specialised interventions can fundamentally address inequities as observed in education. Yet, attempts at 'conscientização' within schools are likely to face resistance both from those whose interests lie in established structures and those who may not benefit from these structures but feel comfortable in them due to long-term exposure - what Bourdieu and Passeron (1990, p. 31) termed 'habitus'. To overcome this problem, certain strategies are proposed which, without being too subversive, can, nevertheless, conscientise students. These 
would appear to fulfil the performative role of technical interventions (e.g. helping individuals achieve academically or prepare for jobs) but in a way that 'conscientização' also occurs. These strategies would endorse the principles of Participatory Action Research (PAR) as conceptualised by Glassman \& Erdem (2014), who drew on Freire's (1996) critical pedagogy, yet not explicitly identified as such.

In the following sections, we first elaborate on the ideology of competitive individualism and the related concept of social mobility which, to a large extent, constitutes the focus of current school practices aimed at promoting equity. It is argued that social mobility constitutes an ineffectual element of what Gillborn (2006) considers 'placebo' interventions; it appears to promote equity by helping disadvantaged students change poles on a hierarchical structure, yet leaving the hierarchy intact. Next, school practices aimed at promoting social mobility are critically reviewed under three headings: targeted support for underachievers; data-driven leadership; and external accountability. The paper concludes by suggesting an alternative approach to addressing inequity which, even though it bears the same characteristics of mainstream 'placebo' interventions, it can, nevertheless, conscientise students (a 'pseudoplacebo'). The paper draws on the works of critical social theorists and philosophers, as well as the physical sciences.

\section{Social mobility as 'placebo treatment' for social inequity}

To critically analyse the notion of 'social mobility' one must first consider those of 'social stratification' and 'social reproduction'. Social stratification is the process by which individuals in society are hierarchically ranked according to commonly accepted criteria. Their position in this hierarchy determines the wealth, status, and power enjoyed over others. An individual's position is influenced by that of their family, and in turn, influences that of their children. A highly ranked family possesses and transmits to its children the resources (i.e. the economic, 
cultural, ${ }^{1}$ and social ${ }^{2}$ capital) needed to achieve a similarly high ranking in adulthood, while the opposite happens when a family has low social standing. This process is known as 'social reproduction' (Bourdieu, 1986; Bourdieu \& Passeron, 1990; Boronski \& Hassan, 2015). Occasionally, people will change positions in the hierarchy relative to their families and such (upward or downward) movement is referred to as 'social mobility' (McKnight, 2015).

The concept of social mobility greatly captured the social imagination during the modern capitalist era, beginning in Europe around the $16^{\text {th }}$ century. It became the antidote to inherited privilege dominant in feudal times, generating hope that people could attain enhanced social position relative to their ancestors through open competition (mainly in the job market) based on personal abilities and efforts (Littler, 2013; Piketty, 2014; Dimitriou, 2017). Such prospects went hand in hand with increased individualisation and detachment from collective identities (e.g. class, family) allowing individuals to 'freely' shape, and take responsibility for, their lives (Beck, 1992). A new ideology of 'competitive individualism' gained appeal. According to it, competition brings out the best in people and is legitimate for distributing limited resources. The inequity it produces is only natural and fair contrary to that associated with patrimony; everyone (the argument goes) will eventually get what they deserve based on 'merit' (i.e. ability combined with ambition/effort). Wanting to compete and win came to be seen as moral virtue and those ambitious enough as deserving societal members driving collective progress (Doherty 2007; Littler 2013; Kulz, 2017).

In this context, education has been viewed as main driver of social mobility, particularly since the advent of the welfare state (post-World War II) and the institutionalisation of social rights. In public conscience, schools have been depicted as equipping young people with the knowledge, skills, and credentials needed to compete successfully in varied domains - a function considered particularly important for students from low status households whose families lack such valued forms of capital (Francis \& Wong, 2013; Dimitriou, 2017). Since the 
1980s, school improvement research and policy have systematically tried to break the cycle of social reproduction through focused interventions helping low socioeconomic status children do better in school and increase their chances for upward mobility (Ainscow et al., 2010; Hopkins et al., 2014). Such enhanced opportunities are often regarded as 'social equity'; the latter is defined as equal chances to move up the social ladder and become like one's 'betters', leaving society's pyramidal shape unchanged (CASE, 2014).

Interventions of this nature, however, have received two related criticisms. The first one concerns their limited effectiveness in reducing the attainment gap between students from different social strata and in improving the life chances of those considered 'disadvantaged' (Ainscow et al., 2010; Ball, 2013). Leaving aside the reported shortcomings of the methods used to evaluate such interventions (Ainscow et al., 2010; Hopkins et al., 2014), their limited impact is generally attributed to a focus on improving a narrow set of skills, knowledge, or dispositions while neglecting the multidimensional nature of inequity necessitating measures beyond schooling, including health care, housing, employment, or the environment to name but a few (Wrigley, 2008; Ainscow et al., 2010; Thompson, 2013; Antonelli et al., 2014; Binelli et al., 2015).

The second criticism - going one step further - concerns the neutral view of education these interventions adopt. Their developers try to identify ways of supporting students to achieve certain learning outcomes naturally viewed as those valuable in life. What remains concealed is that curricula are not value-free entities, but constructed by teams representing social elites (e.g. subject specialists, politicians). They, therefore, contain the culture of those in power (arbitrarily viewed as superior to that of lower-status groups) and operate to their interest. Students from low status households, instead of being empowered to capitalise on their own cultures and aspirations, are forced to adjust to the supposedly superior forms of knowledge, skills, values, and norms that schools represent. They are graded and rewarded 
based on criteria representing the cultural capital of upper social strata, for instance ways of using language, mannerisms, artistic tastes, or opinions. This is not equality but a form of cultural colonialism, ${ }^{3}$ and eventually, only a minority of the socially disadvantaged achieve upward mobility (Bourdieu \& Passeron, 1990; Wrigley, 2008; Collins, 2009; Ballantine \& Spade, 2015; Boronski \& Hassan, 2015; Dorling, 2015; Wilkins, 2015).

Hence, despite the hope generated by opportunities to openly compete for upward mobility in modern capitalist societies, empirical evidence shows that people's fates remain strongly tied to their parents' status (Lee \& Solon, 2009; Chetty et al., 2014; Clark, 2014; Piketty, 2014) and that investing in education to improve one's social position is, at best, questionable (Causa et al., 2009; Francis \& Wong, 2013; Chen et al., 2015; Bukodi, 2016). Moreover, social mobility has been critiqued as a fundamentally problematic concept, because, by definition, it requires losers and cannot be universally achieved. It assumes a pyramidal shape of society which does not allow room for everyone to enjoy the advantages of the top. For an individual to move up the social pyramid, someone else has to move downwards to create space (Littler, 2013; Dorling, 2015). Hence, competitive individualism does not differ much in its fundamental assumptions from beliefs prevalent in feudal times about the hierarchical order of society. It remains within the realm of 'power over' cultures of asymmetrical societies (existing for the last 5,000 years) that view humans as inherently unequal, unlike earlier egalitarian societies characterised by sharing practices and the absence of leaders and private property (Woodburn, 1982; Rogers, 2012; Dimitriou, 2017).

When society is viewed as naturally uneven, the fact that some people achieve more, and enjoy greater rewards in life, than others seems logical. Acquiring 'power over' others is considered fair for those who 'deserve' it and necessary for the well-being of society. Equity, then, has come to be defined as 'fair competition' (Schoon \& Parsons, 2002; Apple, 2008; Wrigley, 2008; Ballantine \& Spade, 2015; Wilkins, 2015; Giannakaki \& Batziakas, 2016). This 
meritocratic philosophy is embedded in school language worldwide and is evident in the frequent use of words such as 'ability' or 'potential' (Littler, 2013; Dorling, 2015; Giannakaki \& Batziakas, 2016).

The emphasis on the individual and his/her potential sidelines collective forms of being and doing which could set the grounds for social reform (Haydon, 1997; Littler, 2013). What it achieves, however, is social stability by curbing the resistance of lower-status groups who, since the rise of capitalism, have hoped to improve their position (relative to others) through competitive work in the market, leaving social asymmetries unchallenged and intact (Biesta \& Lawy, 2006; Torres, 2013; Piven, 2015; Dimitriou, 2017).

The concept of social mobility, then, takes current social structures for granted and no change to these is considered; movement within current structures is the greatest aspiration. Yet, enhancing social mobility is not truly addressing inequities as, even should individuals become socioeconomically mobile, oppressive structural inequities remain. Therefore, school practices attempting to address the socioeconomic gap by encouraging social mobility cannot truly engage with the real problem and could be described as 'placebos'.

\section{School practices supposedly addressing inequity}

The following sections consider practices proposed to address social inequity, yet remaining within the confines of social mobility discourse. These are not exhaustive but (we believe) illustrative of a tendency to view education as laboratory of experts subjecting children to scientifically validated processes of developing certain (expert-certified) learning outcomes. The latter are individualised and operationalised through standardised metrics, allowing universal comparisons expected to guarantee 'fair' competition. These practices appropriate a positivistic philosophy (analysed in more detail later) for imposing a social order which 
disparages understandings of the world not in line with 'official' knowledge ascertained as 'objective' by high-status groups (Apple, 1993; Granger, 2003; Giroux, 2011; Thomson, 2013).

These practices are grouped under three headings: targeted support for underachievers; data-driven leadership; and external accountability. These categories capture practices implemented at different system levels, namely the classroom, the school, and the region/nation. These are not independently implemented but may overlap or be organically combined. Both practices which are 'successful' within their own terms, and those which are not, are considered. For the 'successful' ones, it is argued that the outcome is only a proxy which, while supposedly connected with remedying social inequity, it does not essentially address it.

\section{Targeted support for underachievers}

These practices aim at helping under-achieving students through largely individualised support. Those targeted may include students from working-class families, ethnic minorities, children in care, or those considered to have special educational needs. Even though some of these programmes have as primary goal the provision of alternative learning experiences likely to attract those disaffected by standard curricula (whose unidimensional view of knowledge fails to engage certain groups) they ultimately seek to reduce 'deficits' in academic skills or 'improve' students' socio-emotional skills/behaviours in a way that renders them better attuned to existing school cultures (Ainscow et al., 2010). It is noteworthy that such adjustment is geared to the dominant culture of schools and society as is.

For example, Persson (2013) studied a Swedish school which removed streaming (i.e. grouping by ability) and included special needs students (identified as those who 'could not keep up with the pace or absorb the contents of the teacher's lesson') into regular classes to improve their learning (p. 1211). This was supplemented by individualised support, including 
the presence of special needs teachers in regular classes, homework assistance, and 'holiday schools'. The programme also fostered an alternative pedagogy characterised by researchinformed teaching, clarity of learning goals, carefully structured lessons, obvious teacher authority, and high expectations for all. The programme was largely successful (in its own terms), bringing about improvements in academic outcomes.

Murray and Malmgren (2005) studied a less successful mentoring programme implemented in a high-poverty area school of the USA to improve the socio-emotional 'adjustment' and academic outcomes of adolescents with behavioural problems. The intervention, which aimed to enhance teacher-student relationships, consisted of teachers being assigned as mentors to individual students and developing a programme of meetings during which student aspirations, and strategies to achieve these, were discussed. Using a randomised control group design, no positive impact on students' socio-emotional adjustment was found, yet, some impact was observed on their grade point averages.

Finally, Grimaldi (2012) reports on an ethnographic study of an intervention in an urban high school of Naples aiming to combat low achievement and dropout. The intervention included individualised education plans for at-risk students, special psycho-pedagogical support for them and their families, and capacity building activities for teachers. Even though it started as an ambitious programme, it eventually became a series of standardised recipes for dealing with 'difficult' students from 'poor cultural background[s]' (p. 1138), ignoring the multidimensional nature of underachievement and dropout related to broader societal structures. Four years later, dropout rates were higher than at the outset of the intervention. It was, therefore, judged as an unsuccessful initiative within its own terms.

The above interventions share an emphasis on enhancing academic outcomes for socially disadvantaged students. Even though some may also seek to promote socio-emotional learning, it is the academic gains that constitute the principal indicator of success. Better 
academic outcomes are assumed to be intrinsically good, enhancing students' life chances and contributing to social mobility. Yet, as analysed earlier, this is not the case since inequity is a multidimensional phenomenon requiring a holistic solution. Studies have shown, for example, that students with below average academic performance, but who are from advantaged backgrounds, are more likely to obtain degrees, get senior work positions, and enjoy high earnings as adults than students with above-average performance from disadvantaged backgrounds (Schoon \& Parsons, 2002; McKnight, 2015).

Another common feature of these interventions is enhanced pedagogical individualism. As considered above, this individualism can discourage collective forms of existence and thought, instead making the individual the focus of attention and the subject of improvement, with others (their 'betters') as benchmarks. The student is helped to adjust to an antagonistic system and effectively compete against peers to achieve system-determined objectives. The intervention acquires an instrumental character aiming to increase students' 'feel for the game' (Bourdieu, 1990, p. 63) so they can skillfully seize the valued resources needed to achieve good social standing. This individualistic and competitive system is taken as given and its arbitrary (constructed) character remains unseen; people cannot sense the possibility of working together democratically towards transforming it - what Castoriadis (1991) termed 'the project of autonomy'. ${ }^{4}$

Interventions that help disadvantaged students improve their 'feel for the game' and better navigate a competitive system of unequal educational (and social) opportunities can be detrimental to creating the conditions for 'conscientização' and social reform. For, if the havenots are exposed to the benefits enjoyed by those possessing legitimate culture/power, they will aspire to become like them, reinforcing the oppressive regime weighted against them. Moreover, when those (low-status) students subsequently fail to move up the social pyramid, they are likely to blame themselves for this and be blamed by others. ${ }^{5}$ Such stigmatisation will 
further disempower them (Freire, 1996; Wilkins, 2015). Therefore, no matter how successful such targeted interventions may be within their own terms, they do not promote equity but reaffirm a status quo that advantages the advantaged and further disempowers the disadvantaged. ${ }^{6}$

\section{Data-driven leadership}

Another way of promoting equity through education (related to the interventions analysed earlier) has been through leadership practices driven by 'data' or 'evidence'. These terms refer to objectified metrics, including student scores on (external or school-based) assessments, attendance rates, records of expulsions/suspensions, or graduation rates serving to track the 'progress' of different student groups, compare them, and decide what actions are needed to help those 'lagging behind'. Such data-informed leadership is considered a key competence of principals committed to promoting social justice, allowing them to plan strategically for the improvement and equalisation of learning outcomes (Knapp et al., 2007; Theoharis, 2009; Mandinach \& Honey, 2008; Moses, 2013; Demski \& Racherbäumer, 2015).

In the above context, a rhetoric of successful leadership styles for helping schools achieve their data-driven targets has proliferated. Popular among educationists are transformational, distributed, and instructional leadership styles, which have also been the focus of empirical research over the last 30 years, indicating positive effects on student learning especially in high-disadvantage areas (York-Barr \& Duke, 2004; Leithwood \& Jantzi, 2008; Day et al., 2008; Robinson et al., 2008; Leithwood \& Sun, 2012). Transformational leadership is described as largely based on personal charisma, inspiring school members to go the "extra

mile' and work towards a shared vision (Leithwood \& Jantzi, 2009). Instructional leadership focuses on achieving a common purpose by offering direct guidance on teachers' classroom pedagogy and how it can be aligned with the targets set (Robinson et al., 2008; Halverson et 
al., 2015). Distributed leadership is leadership shared among school members who combine their diverse capacities (in working groups, forums, etc.) to serve the common purpose (YorkBarr \& Duke, 2004; Demski \& Racherbäumer, 2015). Attention has also been paid to interschool collaborations or 'system leadership' (Hopkins et al., 2014, p. 268) aimed at diffusing 'good' practice and 'world-class' expertise across schools/jurisdictions for improving students' learning as defined by universal standards.

Yet, despite positive effects on student outcomes, such leadership approaches have received strong criticism. Lumby and Coleman (2007) point to the strong harmony bias evident in the vocabulary of their proponents (e.g. 'common', 'shared', 'together') and behind which vested interests and undue concentration of power are hidden. According to these models, a 'good' leader is one who forms strong (bonded) communities by bringing people together and inspiring (or guiding) them to work towards common goals agreed through a consensusbuilding process. The 'common' goals 'agreed' usually refer to system-determined outcomes quantifiable and tractable through the use of data (e.g. students' academic performance or engagement with school as is) and whose legitimacy is rarely challenged. Questions such as who influences the target-setting discussions the most, whose interests are served by the 'agreed' targets, or what happens to those disagreeing with these, remain unexplored. Lumby and Coleman (2007) also point to the exclusion of low-status individuals from key leadership roles which potentially affects the outcomes of such consensual processes. Therefore, even though these leadership practices may occasionally promote social mobility and appear successful from an instrumental viewpoint, in the long term, they work to the benefit of dominant social groups and reproduce the social order.

\section{External accountability}


External accountability mainly refers to the monitoring of school processes (e.g. classroom/leadership practices) and the measurement of school outcomes (e.g. test scores, attendance rates) through standardised procedures known as 'inspections'. These are conducted by external experts to generate evidence that schools make good use of public money (often in value-added terms ${ }^{7}$ ) rendering this accessible to parents, governments and/or the public (MacBeath, 2006).

There is variation in form across countries. In England, for example, the combination of open enrolment and free public access to inspection reports means that those schools judged to perform well get a boost to their reputation and may correspondingly increase their enrolments. Underperforming schools may be subjected to remedial interventions (MacBeath, 2006) or, in grave situations, given direction to be closed down as defined by the School Standards and Framework Act 1998 (Meredith, 2012). Germany or Cyprus, on the other hand, have low-stake inspection regimes with no sanctions for underperforming schools (Brauckmann \& Pashiardis, 2010; Demski \& Racherbäumer, 2015).

In general, the positive and/or negative rewards are expected to incentivise teachers and leaders to work harder towards improving the quality of education irrespective of their students' backgrounds. Moreover, monitoring school performance across a country allows the identification of unequal outcomes between regions and/or certain student groups which can then be addressed through targeted interventions.

Research shows, however, that inspections often cause a drop in student academic outcomes, especially in the year of inspection (Scanlon, 1999; Gaertner \& Pant, 2011; Gaertner et al., 2014; Hopkins et al., 2016). The same studies also reveal that inspections have either a negative effect on student performance or none at all. Explanations include teacher stress caused by pressures to meet external thresholds, and the elimination of time for reflective and creative thinking (Scanlon, 1999; Wilkins, 2015). Even when schools have good inspection 
results, this is often the outcome of inappropriate and damaging pedagogical practices (Ball, 2013). From an equity perspective, schools located in disadvantaged areas that perform well in valued-added terms are not equally rewarded as schools in high-status areas. The latter continue to enjoy greater popularity and offer bigger advantages to their graduates than the former (Thrupp, 2001a; Thrupp, 2001b). Inspections have also been critiqued for their limited validity and reliability, not least because the performance measures applied do not cover the entire spectrum of learning possible in a school (and much of which cannot be measured) (Gaertner \& Pant, 2011; Wilkins, 2015). Given the above, external accountability is considered unsuccessful in promoting social equity from various perspectives.

\section{Positivistic underpinnings of 'education for equity' in late modernity}

The practices discussed above are grounded in the epistemological traditions of positivism, empiricism, and operationalism (Marcuse, 1964; Granger, 2003; Hjørland, 2005). Their main assumptions are (a) that the world is an objective entity discoverable through rational inquiry based on sensory experiences (i.e. empirical observations), and (b) that it is divisible into wellbounded and loosely connected parts which can be mapped and measured. Such fragmentation of reality becomes necessary for its precise definition and 'proof' of existence through measurement.

For example, the learning outcomes targeted through the above-described practices, include pieces of knowledge, skills, or attitudes that can be operationalised and measured using standardised tools developed by 'experts'. These outcomes define the 'performance standards' used to evaluate students, teachers and/or schools. The learning processes generating these outcomes are considered divisible into distinguishable parts/steps with a clear sequence referred to as 'structure'. The provision of individualised support to those struggling to meet such standards (be they students, teachers, or schools) implies that a classroom, school, or 
system consists of largely disconnected parts (i.e. students, teachers, or schools, respectively) progressing or failing irrespective of what others do.

In late (neoliberal) modernity, this positivistic outlook has been appropriated by powerful groups to ensure control over others in a supposedly free society (apparently offering increased freedom of choice/action through the marketisation of many spheres of human activity including education and healthcare) under the guise of 'rationality' and 'rigour' (Giroux, 2011; Thomson, 2013; Monbiot, 2016). Sadly, the fragmentation of experience and knowledge in schools precludes holistic understandings of the world necessary for the development of critical consciousness among students, while the individualisation it induces curbs collective action. Education acquires a technicist character, merely helping students adjust to a known and static world without attempting to remake it. When political questions are asked (e.g. 'whose knowledge do schools promote?', 'who does this knowledge serve?', (who defines justice?') those asking these are at risk of being seen as dysfunctional system agents in need of adaptation (Thrupp, 2001a; Thrupp, 2001b; Wrigley, 2008; Straume, 2016).

In the above context, people's capacity to question the social arrangements governing their lives and self-posit themselves is bridled, generating what Castoriadis terms (1991, p. 162) 'heteronomous societies'. These societies take such arrangements as given, imposing specific truths on individuals which can neither be proved nor rejected and which guide their thinking and actions (e.g. that an 'objective' hierarchy of knowledge exists or that there is an irrefutable necessity for continually improving measurable outcomes).

Modern physics however (e.g. relativity theory, physics of the vacuum) have pointed to the spuriousness of classical scientific assertions pervaded by positivist thought. Discoveries in these fields show that what people perceive as the world around them is merely a creation of their senses; a deformed representation of reality. Physical objects, odours, or music, do not exist beyond these senses. For example, what is called 'matter' is, in fact, energy whose density 
has taken such values as to be perceptible to the senses. Scientists have found no solid material substance in the atomic nucleus, but only vibrating energy (Muses, 1972; Danezis \& Theodosiou, 2015).

Given the spuriousness of 'empirical observations' on which positivist philosophy has largely been founded, what is considered 'valid', 'objective', or 'true' should always be revisited. This resonates with Castoriadis' (1991) concept of the 'autonomous society' which constantly interrogates, explicitly and collectively, the 'truth' forming the foundation of its laws/institutions. Such interrogation aims to empower people, so that they do not passively accept social institutions, but constantly recreate these in a politically conscious manner. Castoriadis (1991) argues that being able to question societal institutions does not mean that all ideas are equally valid or that one can do anything they like. The critique of 'truth' should be based on collective deliberation and justification, and combined with care for others and the capacity for self-restraint.

In the next section, we discuss how education could contribute to the development of a critical democratic dialogue among young people which could trigger a shift away from the present oppressive line of thought and sow the seeds for social reform.

\section{Reconceptualising placebo treatments}

Despite critiques that education contributes to social reproduction, Freire (1996), Castoriadis (1991), and Giroux $(1997,2011)$ considered it fundamental in achieving social reform. While then, in terms of addressing social inequity, individualistic and rationalistic solutions are no more than a 'placebo' as they leave oppressive structures intact, we must consider what other forms of intervention might have a liberating effect.

This section considers the placebo metaphor from another angle, namely that the 'placebo effect' is an observed medical phenomenon: sometimes patients respond positively to 
the administration of placebos. It has been observed that placebos administered by staff in white coats have stronger effects, and that placebos injected appear stronger than those taken orally: the manner in which placebos are administered makes a difference (Brown, 2013; Ramzy et al., 2015). Given then, that educational initiatives aimed at addressing social inequity may be placebos, how can they best be administered so as to maximise positive outcomes?

Defining a positive outcome, in this context, is not straightforward. As shown, interventions aimed to address social (in)equity are overly interested in improving students' academic outcomes. However, as discussed, better academic outcomes do not necessarily improve the long-term life opportunities of those considered 'disadvantaged'. This thoughtparadigm is implicated in an individualistic, meritocratic, and rationalistic worldview promoting a social mobility in which the 'deserving' members of the oppressed classes may work their way into a slightly less-oppressed condition, leaving the situation of others unchanged.

Instead of promoting social mobility, mechanisms for restructuring society, for creating social equity, or for taking steps in that direction, should be the desirable outcomes of educational interventions. Bourdieu and Passeron (1990), however, assert that formal education is a conservative mechanism reproducing dominant norms and structures, and maintaining any pre-existing social inequity. 'Misrecognition' is their term for the fact that school members do not perceive that the culture being passed on to them as legitimate is in fact a 'cultural arbitrary' (p. 5) and that the system tacitly privileges individuals belonging to the dominant culture, while the marginalised or oppressed are further disadvantaged.

At the risk of anachronistically blending concepts from different theorists, it is here argued that the 'conscientização' of the oppressed will free them from the 'misrecognition' which traps them into accepting that existing structures are the only possible way for society to exist. Examples of applying a critical pedagogy, such as that described by Freire (1996), in 
teacher training programmes for the purposes of achieving 'conscientização' have been described in the USA (Apple, 2008; Martin, 2005). Ellsworth (1989, p. 297), however, argues that, in a traditional classroom, aspects of critical pedagogy continue to 'perpetuate relations of domination' and that critical pedagogues are implicated in the very structures they seek to subvert. Freire (1996, p. 36) himself acknowledges that "the pedagogy of the oppressed cannot be...practiced by the oppressors'. Teachers, however progressive their individual outlook, are cast in the role of authority, the passer-on of dominant culture, whether they like it or not.

Hence, the application of a critical pedagogy (originally inspired in the field of adult/community education) does not seem immediately suited to being transplanted into a compulsory school system. In the UK, for example, even were it to be tolerated by the various inspectorates, the disruption caused by the clash between the new and the old pedagogy would potentially cause the change to fail catastrophically. Resistance could arise from students themselves, as new generations have been raised with neoliberal values that challenge the notions of equity, citizenship, and democracy (Torres, 2013).

Mechanisms are needed which will be both accepted by the system and effective within it; this is where our 'placebo effect' can be useful. It must be acknowledged that the strategy here presented, while inspired by the concept of the placebo, rather stretches the metaphor to the point of breaking. A summary of the underlying thought process is that if it should be the case (and we do not concretely suggest that it is) that the education practices categorised as 'placebos' are in fact intentionally ineffective, then, to gain acceptance, any proposed initiative must at least appear to also be a placebo but not meant as such (i.e. a 'pseudo-placebo'). The next section explores a strategy that might work in such a way.

\section{Participatory Action Research as 'pseudo-placebo'}


Participatory Action Research (PAR) may be a mechanism for promoting, through education, a paradigm shift towards a more democratic and equitable society. Barua (2009, p. 241) describes PAR as:

... an active process in which disadvantaged groups are empowered through collective education and partnership... Such research is politically committed toward structural social change to dismantle the dominion of the minority group who control the wealth of the society... [It] allows marginalised people to generate their own knowledge from their daily experiences to liberate them from social oppression.

In the school context, PAR can engage students in political dialogue promoting awareness of oppressive school structures and actions that improve equity outcomes.

One should take care to distinguish between PAR and the mainstream Action Research applied in the context of the school effectiveness and improvement movement. PAR is intimately related to the political struggle for liberation from hegemonic societal arrangements which is undertaken collectively; it promotes a revolutionary social critique to raise students' awareness of their position within existing power relations networks and of how these circumscribe their identities and actions. Hence, PAR is explicitly aimed at social transformation and has an explicit collective character. PAR, then, may be a mechanism for subverting the social reproductive function of schools. Action Research, on the other hand, is used in relatively uncontroversial contexts to optimise, rather than subvert, established school processes and outcomes (Martin \& McLaren, 2006; Glassman et al., 2012; Glassman \& Erdem, 2014). Action Research may adopt the same individualistic and/or rationalistic approaches of mainstream 'education for equity' interventions. For example, while Action Research may involve teachers (in a given context) exploring together ways of improving students' mathematical comprehension, PAR would aim to uncover the power relations and wider 
political interests served by this subject specialism, challenging its form and/or place in the curriculum. Despite being geared towards maintaining the status quo, Action Research could still prove useful; it could provide the performative 'cloak' under which to conceal PAR's subversive character.

Before explaining this in more detail, some further analysis of the concept of PAR could prove useful. PAR can be recognised by its 'mirror concepts of 'vivencia', 'praxis', and 'conscientisation",8 (Glassman \& Erdem, 2014, p. 206). 'Vivencia' corresponds with 'participatory', 'praxis' with 'action', and 'conscientisation' with 'research'. Vivencia is the lived experience of events through direct participation. Praxis means acting upon the life conditions one faces with the view to changing them. Conscientisation is the moment people realise their oppressive socio-cultural reality and their capacity to transform it. It is the point they understand that old oppressive practices are not that critical to their survival but can be changed to redefine their lives.

In the practical context of the classroom, PAR may involve students working in small groups to examine common problems as experienced and defined by them. Such problems should be framed in a way rendering them not just personally relevant, but 'socially... serious' as well (Apple, 2008, p. 256). Apart from being empirically grounded, the examination of these problems should be critical, aiming to unveil the underlying power relations that generate and perpetuate varied forms of oppression. Such deep understanding necessitates direct experience of the problem (vivencia). Hence, educators should find ways to participate in the social contexts of students or recruit members living that experience. It is important that students question the power relations underlying the problems examined and understand that these are a product of history which need not be maintained (conscientisation) (Freire \& Macedo, 1995). This will empower them to take collective action to undo such relations and transform their lives (praxis). What lies at the heart of PAR, then, is an ethic of critique, the courage to dissent, 
openness to deliberation, a genuine care for the collectivity, and a commitment to change. PAR is therefore intensely political (Herr \& Anderson, 2003; Expósito, 2014; Glassman \& Erdem, 2014).

Given its political character, for PAR to be accepted by the system, it must be (mis)interpreted as a mainstream 'placebo' intervention. Such misinterpretation of PAR does not seem difficult to achieve; PAR is not always understood as a political endeavour. The term has been applied to varied practices with little in common other than that the research was conducted 'with' the people involved (Heron \& Reason, 2001). Jordan (2009) acknowledges that the term PAR is often used interchangeably with the concept of Action Research. For example, Whyte (1991) is concerned with exploiting PAR to achieve change in a management context, which leads Jordan (2009, p. 18) to argue that PAR, despite its radical social origins, has been susceptible to neoliberal appropriation by mainstream government agendas and multinational corporations so as to 'reconstitute PAR as a tool of capitalist accumulation'. Yet, it is this very ambiguity and vulnerability which renders PAR a powerful pseudo-placebo; if PAR were riotously subversive in its every incarnation, it could never pass as acceptable within a mainstream institution. To function well, it must appear (and to some extent be) one thing, while subverting itself and the system by providing a framework for the development of 'conscientização'.

Hence, PAR can potentially be misrecognised (and therefore allowed) by both students and the legitimised education authorities as traditional 'Action Research'. It can thus form the beginnings of a Freirean dialogic model of pedagogy within institutions where the 'banking'9 mode of education is prevalent. It is for this reason why we refer to such PAR as a 'pseudoplacebo'; it does not initially appear to be subversive, but, instead, seems to fulfil the performative role of mainstream interventions (e.g. raising scores, preparing students for jobs). However, it does this in a way that 'conscientização' also occurs. Such PAR, even though it 
would bear the performative element of 'playing the game' of social mobility, it would do this explicitly, accepting that the game exists without normalising it or making it seem as the only way society or education can function. By engaging students in the critical study of socially important problems, it would make clear the (otherwise invisible) rules of this game (i.e. revealing the system's predominant function of preserving the status quo) and suggest that these rules can be changed. The performative character of such a 'pseudo-placebo' would not only be necessary to have it approved by the authorities, but also by the oppressed ('disadvantaged' students) who do not realise the potential for liberation through acting in solidarity with each other, and instead, desire individual outcomes to get qualifications and jobs.

Mainstream subjects (e.g. English, maths, physics) may serve the above purpose; that is, fulfilling the performative role of preparing students for high stakes examinations, while raising their critical consciousness, especially if they are interdisciplinarily taught through links with other disciplines (humanities and social sciences) allowing their study through a sociopolitical lens. In this way, mainstream subjects can become the means to developing new holistic understandings of the world rather than an end in themselves (Freire, 1996). It may also be necessary to invite classroom or other external assistants to facilitate such PAR projects; having teachers as facilitators may result in what Martin and McLaren $(2006,184)$ describe as 'manipulative power dressed up as emancipation'. As already argued, if teachers facilitate PAR they may unduly influence the framing and analysis of problems examined given their authority vis-à-vis students. ${ }^{10}$

It is acknowledged that a PAR approach aligned with existing school structures to conceal its subversive character entails the risk of becoming another 'placebo' intervention, hence losing its transformative power. Nevertheless, we believe that PAR has potential to be 
an engine for social change via a traditional school environment and that this potential is worthy of further investigation.

\section{Conclusion}

This paper used Gillborn's (2006) 'placebo' metaphor to critique school programmes implemented internationally with the view to tackling social inequities. It was argued that such programmes remain 'locked' in the logic of social mobility, reaffirming the legitimacy of a hierarchical system which unfairly distributes social opportunities and is underpinned by the ideology of competitive individualism. Such practices are so ingrained in daily school life that it would be difficult to blatantly expose the subtle injustices they embed without provoking harsh resistance. A mechanism has, therefore, been suggested for raising students' awareness of such injustices without being explicitly subversive of the system. This would entail the application of PAR under the guise of mainstream 'Action Research'. Such PAR would come across as another 'placebo' intervention fulfilling the performative role of more technical projects (e.g. raising students' scores) yet in a way that 'conscientização' in the Freirean sense also happens in the process. The aim would be to eventually challenge the reproductive function of education and plant the seeds for social reform.

The current neoliberal era is considered as the last phase of a dying (capitalist) paradigm which, having exceeded its limits as evidenced in the depletion of natural resources and upsurge in poverty, needs to be replaced by a new form of civilisation based on collectivity and solidarity (Foster \& Clark, 2009; Arvanitis, 2015; Danezis \& Theodosiou, 2015; Dimitriou, 2017). This, then, might be the right time to apply PAR in varied educational sites. The punctuation equilibrium model of change may be of relevance here (Parsons \& Fidler, 2005). According to it, deep change is possible only at particular periods of punctuation (crises). The current socioeconomic and political crisis experienced internationally may constitute the 
punctuation foreshadowing the birth of a new civilisation. It might, then, be the right moment for educators to work towards the 'conscientização' of future generations to hasten the arrival of the new civilisation and ensure that the change, when it comes, will be in the desired direction.

For educators to be able to facilitate PAR, however, educational foundations should acquire a prominent place in teacher and leader preparation programmes. The latter need to draw insights from anthropology, history, sociology, philosophy, and political science to help future teachers/leaders 'understand why schools operate the way they do' and to critically assess the dominant beliefs, policies, and practices characterising the education system (Hartlep \& Porfilio, 2015, p. 309). This would help overcome the commonly encountered 'stir-andserve' (anti-intellectual) character of such programmes which over-emphasise classroom and staff management skills, as well as techniques for 'effectively' teaching subjects to improve results (Ohanian in Hartlep \& Porfilio, 2015, p. 309). To be meaningful, however, insights from foundation disciplines would need to be connected to the lived experiences of different student groups. Hence, teacher and leader development programmes should incorporate the conduct of PAR itself, including asking their attendees to spend time living close to students (Martin, 2005).

A further step might be the implementation of incentives for practicing teachers and leaders to go to a different school community and spend time in the liminal role of "classroom assistant' engaged in PAR projects. This could have a powerful impact especially if the outcomes of those projects were shared in a structured and reflective manner. On a less radical level, teachers and school leaders can be challenged to consider their own role in either sustaining or subverting social inequity, and encouraged to facilitate the implementation of PAR programmes within their own institutions. 
The current global socio-economic crisis could be seen as the 'labour pains' signaling the coming of a new civilisation. We hope that this civilisation will embrace the values of equity, solidarity, and collectivity. After all, what research shows is that more equal societies do better in human development, economic performance, and political stability (Binelli et al., 2015).

\section{NOTES}

1. Cultural capital refers to symbolic elements (e.g. mannerisms, language, credentials) acquired through belonging to a social group. Certain forms of cultural capital are valued more than others, helping individuals enhance their status in the same way as income (Bourdieu, 1986).

2. Social capital refers to resources enjoyed through having durable relationships with members of a group. These offer individuals access to tangible and/or intangible resources not accessible otherwise (Bourdieu, 1986).

3. Amsler (2007) defines cultural colonialism as '...the asymmetrical influence of one culture over another' (para. 1). The term mostly refers to 'the cultural domination of Southern societies by the global North in the context of global capitalism' (para. 1) but also denotes the imposition of ways of life pertaining to powerful groups in a given territory onto other (non-dominant) groups through means such as education, the media, or the official language.

4. Castoriadis (1991) defines 'autonomy' as the capacity of calling into question society's established norms and institutions with the view to explicitly reinstituting it through genuine deliberation.

5. Such blame is often based on the argument that some other people from disadvantaged backgrounds achieved against odds and socially progressed based on 'merit'. If others can 
do it, this is considered sufficient evidence for the existence of fair opportunities for everyone to progress (Giannakaki \& Batziakas, 2016).

6. In the context of this critique, it is not our intention to deny the significance of evidencebased practices in special education aimed at empowering children to be actively involved in school life (e.g. behaviour-analytic interventions for students with Autism Spectrum Disorders) (Myers \& Johnson, 2007). Our critique is rather concerned with forms of individualised support focused on narrowing attainment gaps according to predetermined, quantifiable outcomes, denying a dialogic relationship between the learner and the world that bears transformative potential (Wayne, 2013).

7. When a school performs well in 'value-added terms', its students perform better than what would be expected on the basis of their socioeconomic background or previous attainment alone. Hence, even if school A (a hypothetical case) performed equally well on a standardised test as school B, it would be considered more effective in value-added terms if its students came from lower socioeconomic backgrounds or had lower performances in earlier tests than students in School B.

8. 'Conscientisation' is the English translation of the Portuguese term 'conscientização'.

9. 'Banking education' refers to a transmissive teaching and learning model, whereby 'objective' knowledge is transferred from 'expert' teachers to 'ignorant' students expected to absorb it passively and uncritically (Freire, 1996, p. 54).

10. It is not argued that classroom assistants (or other ancillary staff) are more able than teachers to sympathise with oppressed student groups, but that their less fixedly determined role within the school allows them to function more easily in the role of social liberator. The classroom assistant is, by definition, not a teacher, and is thus free from being cast into a role likely to bring associations of authoritarianism and to induce submission rather than subversion even in the most progressive context (McClure, 2003; McMillan, 2016). 


\section{References}

Ainscow, M., Chapman, C., Dyson, A., Gunter, H., Hall, D., Kerr, K., McNamara, O., Muijs, D., Raffo, C. \& West, M. (2010) Insight 2. Social inequality: can schools narrow the gap? (Cheshire, BERA). Available online at: https://www.bera.ac.uk/wpcontent/uploads/2014/01/Insight2-web.pdf (accessed 1 November 2016).

Amsler, S. (n.d.) Cultural colonialism, in: G. Ritzer (Ed) Blackwell encyclopedia of sociology (Hoboken, NJ, Blackwell Publishing). Available online at: http://www.blackwellreference.com/subscriber/uid=967/tocnode?id=g9781405124331 chunk g97814051243319 ss1-203 (accessed 26 June 2017). (Print version published 2007)

Antonelli, G., Calia, P. P. \& Guidetti, G. (2014) Approaching an investigation of multidimensional inequality through the lenses of variety in models of capitalism, Quaderni working paper DSE no 987 (Bologna, Alma Mater Studiorum). Available online at: http://amsacta.unibo.it/4143/1/WP984.pdf (accessed 1 November 2016).

Apple, M. W. (1993) The politics of official knowledge: does a national curriculum make sense? Teachers College Record, 95(2), 222-241.

Apple, M. W. (2008) Can schooling contribute to a more just society? Education, Citizenship and Social Justice, 3(3), 239-261.

Arvanitis, V. (2015) State education systems and totalitarian economy: Greece as a case-study of neoliberalism's failure (2008-2014), Journal for Critical Education Policy Studies, 12(3), 73-103.

Ball, S. J. (2013) The education debate (2nd ed.) (Bristol, The Policy Press).

Ballantine, J. H. \& Spade, J. Z. (2015) Getting started: understanding education through sociological theory, in: J. H. Ballantine \& J. Z. Spade (Eds) Schools and society: a sociological approach to education (5th ed.) (Thousand Oaks, CA, Sage), 18-34. 
Barua, B. P. (2009) Participatory research, NGOs, and grassroots development: challenges in rural Bangladesh, in: D. Kapoor \& S. Jordan (Eds) Education, participatory action research, and social change: international perspectives (New York, NY, Palgrave Macmillan), 239-250.

Beck, U. (1992) Risk society: towards a new modernity (M. Ritter, Trans.) (London, Sage).

Biesta, G. J. J. \& Lawy, R. (2006) From teaching citizenship to learning democracy: overcoming individualism in research, policy and practice, Cambridge Journal of Education, 36(1), 63-79.

Binelli, C., Loveless, M. \& Whitefield, S. (2015) What is social inequality and why does it matter? Evidence from central and eastern Europe, World Development, 70, 239-248.

Boronski, T. \& Hassan, N. (2015) Sociology of education (London, Sage).

Bourdieu, P. (1986) The forms of capital, in: J. E. Richardson (Ed) Handbook of theory of research for the sociology of education (Westport, Connecticut, Greenword Press), $241-258$

Bourdieu, P. (1990) In other words (Stanford, Stanford University Press).

Bourdieu, P. \& Passeron, J. C. (1990) Reproduction in education, society and culture (2nd ed.) (London, Sage).

Brauckmann, S. \& Pashiardis, P. (2010) The clash of evaluations: in search of the missing link between school accountability and school improvement - experiences from Cyprus, International Journal of Educational Management, 24(4), 330-350.

Brown, W. A. (2013) Expectation, the placebo effect and the response to treatment, Rhode Island Medical Journal, 98(5), 19-21.

Bukodi, E. (2016) Educational attainment - relative or absolute - as a mediator of intergenerational class mobility in Britain, Research in Social Stratification and Mobility, 43, 5-15. 
CASE, (2014) Education, equity and social mobility: a summary of three research papers, Social policy in a cold climate research note series RN07 (London, Centre for Analysis of Social Exclusion, London School of Economics). Available online at: http://sticerd.lse.ac.uk/dps/case/spcc/rn007.pdf(accessed 3 November 2016).

Castoriadis, C. (1991) Power, politics, autonomy, in: D. A. Curtis (Ed) Philosophy, politics, autonomy (New York, NY, Oxford University Press), 143-174.

Causa, O., Dantan A. \& Johansson, A. (2009) Intergenerational social mobility in European OECD countries, OECD economics department working papers no 709 (Paris, OECD Publishing). Available online at: http://www.oecdilibrary.org/economics/intergenerational-social-mobility-in-european-oecdcountries 223043801483?crawler=true (accessed 21 June 2017).

Chen, Y., Naidu, S., Yu, T. \& Yuchtman, N. (2015) Intergenerational mobility and institutional change in $20^{\text {th }}$ century China, Explorations in Economic History, 58, 44-73

Chetty, R., Hendren, N., Kline, P., Saez, E. \& Turner, N. (2014) Is the United States still a land of opportunity? Recent trends in intergenerational mobility, American Economic Review: Papers and Proceedings, 104 (5), 141-147.

Clark, G. (2014) The son also rises: surnames and the history of social mobility (Princeton, New Jersey, Princeton University Press).

Collins, J. (2009) Social reproduction in classrooms and schools, Annual Review of Anthropology, 38, 33-48.

Danezis, M. \& Theodosiou, S. (2015) The future of our past: science \& new civilization (V. Manimanis, Trans.) (Athens, Diavlos Publications).

Day, C., Leithwood, K. \& Sammons, P. (2008) What we have learned, what we need to know more about, School Leadership \& Management, 28(1), 83-96. 
Demski, D. \& Racherbäumer, K. (2015) Principals' evidence-based practice - findings from German schools, International Journal of Educational Management, 29(6), 735-748.

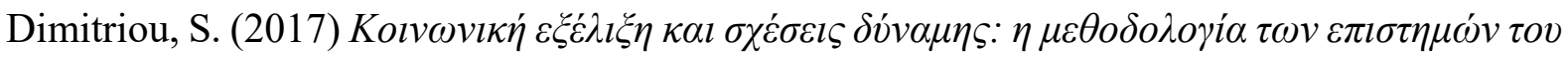
$\alpha \nu \theta \rho \omega ́ \pi \circ v$ [Social evolution and power relations: the methodology of the human sciences] (Athens, Alexandria Publications).

Doherty, R. A. (2007) Education, neoliberalism and the consumer citizen: after the golden age of egalitarian reform, Critical Studies in Education, 48(2), 269-288.

Dorling, D. (2015) Inequality and the 1\% (London, Verso).

Ehrenreich, B. \& Ehrenreich, J. (1979) The professional-managerial class, in: P. Walker (Ed) Between labour and capital (Boston, South End Press), 5-46.

Ellsworth, E. (1989) Why doesn't this feel empowering? Working through the repressive myths of critical pedagogy, Harvard Educational Review, 59(3), 297-324.

Expósito, L. P. (2014) Rethinking political participation: a pedagogical approach for citizenship education, Theory and Research in Education, 12(2), 229-251.

Faubert, B. (2012) A literature review of school practices to overcome school failure, OECD education working papers no 68 (Paris, OECD Publishing). Available online at: http://www.oecd-ilibrary.org/education/a-literature-review-of-school-practices-toovercome-school-failure_5k9flcwwv9tk-en (accessed 14 June 2017).

Foster, J. B. \& Clark, B. (2009) The paradox of wealth: capitalism and ecological destruction, Monthly Review: An Independent Socialist Magazine, 61(6). Available online at: http://monthlyreview.org/2009/11/01/the-paradox-of-wealth-capitalism-andecological-destruction/ (accessed 3 November 2016).

Francis, B. \& Wong, B. (2013) What is preventing social mobility? A review of the evidence. Available online at: 
file:///C:/Users/3048313/AppData/Local/Temp/what is preventing_social_mobility1.pdf (accessed 19 June 2017).

Freire, P. (1996) Pedagogy of the oppressed (M. Bergman Ramos, Trans.) (London, Penguin Books). (Original work published 1970 by Continuum)

Freire, P. \& Macedo, D. P. (1995) A dialogue: culture, language, and race, Harvard Educational Review, 65(3), 377-402.

Gaertner, H. \& Pant, H. A. (2011) How valid are school inspections? Problems and strategies for validating processes and results, Studies in Educational Evaluation, 37(2-3), 85-93.

Gaertner, H., Wurster, S. \& Pant, H. A. (2014) The effect of school inspections on school improvement, School Effectiveness and School Improvement, 25(4), 489-508.

Geobers, E., Geijsel, F., Admiraal, W. \& ter Dam. G. (2013) Review of the effects of citizenship education, Educational Research Review, 9, 158-173.

Giannakaki, M. S. \& Batziakas, G. (2016) 'This is a beautiful school.' 'This school is useless!!' Explaining disengagement in a Greek vocational school through the examination of teacher ideologies, Research in Post-Compulsory Education, 21(4), 409-433.

Gillborn, D. (2006) Citizenship education as placebo: 'standards', institutional racism and education policy, Education, Citizenship and Social Justice, 1(1), 83-104.

Giroux, H. (1997) Pedagogy and the politics of hope: theory, culture and schooling (Oxford, Westview Press).

Giroux, H. (2011) On critical pedagogy (London, Bloomsbury).

Glassman, M. \& Erdem, G. (2014) Participatory action research and its meanings: vivencia, praxis, conscientisation, Adult Education Quarterly, 64(3), 206-221.

Glassman, M., Erdem, G. \& Bartholomew, M. (2012) Action research and its history as an adult education movement for social change, Adult Education Quarterly, 63(3), 272288. 
Gorski, P. C. (2008) Peddling poverty for profit: elements of oppression in Ruby Payne's framework, Equity \& Excellence in Education, 41(1), 130-148.

Granger, D. (2003) Positivism, skepticism, and the attractions of 'paltry empiricism': Stanley Cavell and the current standards movement in education, Philosophy of Education, 146154. Available online at: http://ojs.ed.uiuc.edu/index.php/pes/article/view/1725 (accessed 10 June 2017)

Grimaldi, E. (2012) Neoliberalism and the marginalisation of social justice: the making of an education policy to combat social exclusion, International Journal of Inclusive Education, 16(11), 1131-1154.

Grubb, W. N. (2007) Dynamic inequality and intervention: lessons from a small country, The Phi Delta Kappan, 89(2), 105-114.

Halverson, R., Grigg, J., Pritchett, R. \& Thomas, C. (2015) Creating data-driven instructional systems in school: the new instructional leadership, Journal of School Leadership, 25, $447-481$.

Hartlep, N. D. \& Porfilio, B. J. (2015) Revitalizing the field of educational foundations and PK-20 educators' commitment to social justice and issues of equity in an age of neoliberalism, Educational Studies, 51(4), 300-316.

Haydon, D. (1997) 'Crisis' in the classroom, in: P. Scraton (Ed) Childhood in 'crisis' (London: UCL Press), 103-125.

Heron, J. \& Reason, P. (2001) The practice of co-operative inquiry: research 'with' rather than 'on' people', in: P. Reason \& H. Bradbury (Eds) Handbook of action research (London, Sage), 179-188.

Herr, K., \& Anderson, G. (2003) Violent youth or violent schools? A critical incident analysis of symbolic violence, International Journal of Leadership in Education: Theory and Practice, 6(4), 415-433. 
Hilburn, J. \& Maguth, B. M. (2015) Spatial citizenship education: civic teachers' instructional priorities and approaches, The Journal of Social Studies Research, 39, 107-118.

Hjørland, B. (2005) Empiricism, rationalism and positivism in library and information science, Journal of Documentation, 61(1), 130-155.

Hopkins, E., Hendry, H., Garrod, F., McClare, S., Pettit, D., Smith, L., Burrell, H. \& Temple, J. (2016) Teachers' views of the impact of school evaluation and external inspection processes, Improving Schools, 19(1), 52-61.

Hopkins, D., Stringfield, S., Harris, A., Stoll, L. \& Mackay, T. (2014) School and system improvement: a narrative state-of-the-art review, School Effectiveness and School Improvement: An International Journal of Research, Policy and Practice, 25(2), 257281.

Irizzary, J. (2009) Cultural deficit model, education.com. Available online at: $\underline{\text { http://www.education.com/reference/article/cultural-deficit-model/ }} \quad$ (accessed 3 November 2016).

Jordan, S. (2009) From a methodology of the margins to neoliberal appropriation and beyond: the lineages of PAR, in: D. Kapoor \& S. Jordan (Eds) Education, participatory action research, and social change (New York, NY, Palgrave Macmillan), 15-17.

Knapp, M. S., Copland, M. A. \& Swinnerton, J. A. (2007) Understanding the promise and dynamics of data-informed leadership, in: P. A. Moss (Ed) Evidence and decision making: 106th yearbook of the National Society for the Study of Education (Malden, MA, Blackwell), 74-104.

Kulz, C. (2017) Heroic heads, mobility mythologies and the power of ambiguity, British Journal of Sociology of Education, 38(2), 85-104.

Lee, C. I. \& Solon, G. (2009) Trends in intergenerational income mobility, Review of Economics and Statistics, 91(4), 766-772. 
Leithwood, K. \& Jantzi, D. (2008) Linking leadership to student learning: the contribution of leader efficacy, Educational Administration Quarterly, 44(4), 496-528.

Leithwood, K. \& Jantzi, D. (2009) Transformational leadership, in: B. Davies (Ed) The essentials of school leadership (London, SAGE), 37-52.

Leithwood, K. \& Sun, J. (2012) The nature and effects of transformational school leadership: a meta-analytic review of unpublished research, Educational Administration Quarterly, 48(3), 387-423.

Littler, J. (2013) Meritocracy as plutocracy: the marketising of 'equality' under neoliberalism, New Formations, 80-81, 52-72.

Loughland, T. \& Sriprakash, A. (2016) Bernstein revisited: the recontextualisation of equity in contemporary Australian school education, British Journal of Sociology of Education, $37(2), 230-247$.

Lumby, J. \& Coleman, M. (2007) Leadership and diversity: challenging theory and practice in education (London, Sage).

MacBeath, J. (2006) School inspection and self-evaluation: working with the new relationship (London, Routledge).

MacBeath, J. \& Mortimore, P. (2001) Improving school effectiveness (Berkshire, Open University Press).

Mandinach, E. B. \& Honey, M. (Eds) (2008) Data driven school improvement: linking data and learning (New York, NY, Teachers College Press).

Marcuse, H. (1964) One-dimensional man (London, Routledge).

Martin, R. J. (2005) An American dilemma: using action research to frame social class as an issue of social justice in teacher education courses, Teacher Education Quarterly, $32(2), 5-22$. 
Martin, G. L. \& McLaren, P. (2006) Participatory activist research (teams) / action research, in: K. Tobin \& J. Kincheloe (Eds) Doing educational research: $a$ handbook (Rotterdam, Sense), 157-190.

McClure, M. (2003) Discourse in educational and social research (Buckingham, Open University Press).

McKnight, A. (2015) Downward mobility, opportunity hoarding and the 'glass floor, Research report for the Centre for Analysis of Social Exclusion LSE (London, Social Mobility and Child Poverty Commission). Available online at:

https://www.gov.uk/government/uploads/system/uploads/attachment data/file/447575

/Downward mobility opportunity hoarding and the glass floor.pdf (accessed 3 November 2016).

McMillan, I. D. (2016) Educational identities and expectations in James Herndon's 'The way it spozed to be' (or why progressive teachers should explore drag), Unpublished Master thesis (Belfast, Queen's University Belfast).

Meissel, K., Parr, J. M. \& Timperley, H. S. (2016) Can professional development of teachers reduce disparity in student achievement? Teaching and Teacher Education, 58, 163173.

Meredith, P. (2012) England, in: P. Gearon (Ed) Education in the United Kingdom: structures and organisation (London, Routledge), 3-15.

Monbiot, G. (15 April 2016) Neoliberalism - the ideology at the root of all our problems, The Guardian. Available online at:

https://www.theguardian.com/books/2016/apr/15/neoliberalism-ideology-problemgeorge-monbiot (accessed 3 November 2016).

Moses, E. C. (2013) School leaders sense-making and use of equity-related data to disrupt patterns of inequality, Unpublished doctoral dissertation (Los Angeles, CA, University 
of California). Available online at http://escholarship.org/uc/item/5gw395kd (accessed 15 August 2017).

Murray, C. \& Malmgren, K. (2005) Implementing a teacher-student relationship program in a high-poverty urban school: effects on social, emotional, and academic adjustment and lessons learned, Journal of School Psychology, 43(2), 137-152.

Muses, C. (1972) Consciousness and reality (New York, NY, Outerbridge and Lazard).

Myers, S. M. \& Johnson, C. P. (2007) Management of children with autism spectrum disorders, Pediatrics, 120(5), 1162-1182. Available online at: http://pediatrics.aappublications.org/content/pediatrics/120/5/1162.full.pdf (accessed 13 August 2017).

Ndlovu, M. C. (2011) University-school partnerships for social justice in mathematics and science education: the case of the SMILES project at IMSTUS, South African Journal of Education, 31(3), 419-433.

Oakes, J. (2005) Keeping track: how schools structure inequality (2nd ed.) (New Haven, CT, Yale University Press).

Parsons, C. \& Fidler, B. (2005) A new theory of educational change: punctuated equilibrium: the case of the internationalisation of higher education institutions, British Journal of Educational Studies, 53(4), 447-465.

Payne, R. K. (2013) A framework for understanding poverty (5th ed.) (Highlands, TX, Aha Process Inc.).

Persson, E. (2013) Raising achievement through inclusion, International Journal of Inclusive Education, 17(11), 1205-1220.

Piketty, T. (2014) Capital in the 21st century (A. Goldhammer, Trans.) (Boston, MA, Belknap Press of Harvard University). 
Piven, F. F. (2015) Neoliberalism and the welfare state, Journal of International and Comparative Social Policy, 31(1), 2-9.

Poulter, S. (2016) From citizenship of God's Kingdom to liberal individualism? A critical historical analysis of Finnish religious education, British Journal of Religious Education, 39(2), 187-206.

Ramzy, R., Cindy, G. \& Jason, G. M. R. (2015) Effects of an injected placebo on endurance running performance, Medicine \& Science in Sports \& Exercise, 47(8), 1672-1681.

Robinson, V., Lloyd, C. \& Rowe, K. (2008) The impact of leadership on student outcomes: an analysis of the differential effects of leadership types, Educational Administration Quarterly, 44(5), 635-674.

Rogers, D. (25 July 2012) Inequality: why egalitarian societies died out, New scientist. Available online at: https:/www.newscientist.com/article/dn22071-inequality-why-egalitariansocieties-died-out/ (accessed 26 June 2017).

Scanlon, M. (1999) The impact of OFSTED inspections (Slough, NFER). Available online at: https://www.nfer.ac.uk/publications/91013/91013.pdf (accessed 16 August 2017).

Schoon, I. \& Parsons, S. (2002) Competence in the face of adversity: the influence of early family environment and long-term consequences, Children and society, 16(4), 260-272.

Staeheli, L. A. \& Hammett, D. (2013) 'For the future of the nation': citizenship, nation, and education in South Africa, Political Geography, 32, 32-41.

Straume, I. S. (2016) Democracy, education and the need for politics, Studies in Philosophy and Education, 35(1), 29-45.

Theoharis, G. (2009) The school leaders our children deserve: seven keys to equity, social justice and school reform (New York, NY, Teachers College).

Thomson, P. (2013) Romancing the market: narrativising equity in globalising times, Discourse: Studies in the Cultural Politics of Education, 34(2), 170-184. 
Thrupp, M. (2001a) Recent school effectiveness counter-critiques: problems and possibilities, British Educational Research Journal, 27(4), 443-457.

Thrupp, M. (2001b) Sociological and political concerns about school effectiveness research: time for a new research agenda, School Effectiveness and School Improvement, 12(1), $7-40$.

Torres, C. A. (2013) Neoliberalism as a new historical bloc: a Gramscian analysis of neoliberalism's common sense in education, International Studies in Sociology of Education, 23(2), 80-106.

Wayne, V. (2013) Martin Buber's concept of inclusion as a critique of special education, International Journal of Inclusive Education, 17(6), 614-628.

Whyte, W. (1991) Participatory action research (London, Sage).

Wilkins, C. (2015) Education reform in England: quality and equity in the performative school, International Journal of Inclusive Education, 19(11), 1143-1160.

Woodburn, J. (1982) Egalitarian societies, Man, 17(3), 431-451.

Wrigley, T. (2008) School improvement in a neo-liberal world, Journal of Educational Administration and History, 40(2), 129-14.

York-Barr, J. \& Duke, K. (2004) What do we know about teacher leadership? Findings from two decades of scholarship, Review of Educational Research, 74(3), 255- 316. 